\title{
Epicardial adipose tissue evaluated with cardiac magnetic resonance in normal subject and in patients with ischemic and dilated cardiomyopathies
}

\author{
Francesco Secchi, Andrea Cozzi, Daniel Zambelli, Marcello Petrini, Paola M Cannao, Francesco Sardanelli, \\ Massimo Lombardi
}

From 19th Annual SCMR Scientific Sessions

Los Angeles, CA, USA. 27-30 January 2016

\section{Background}

Epicardial adipose tissue (EAT) is considered a marker of cardiovascular disease because of its pro-inflammatory properties. The aim was to find differences of amount of EAT in three groups of patients evaluated with cardiac magnetic resonance (CMR): 1) negative CMR; 2) patients with coronary artery disease (CAD); 3 ) patients with dilated cardiomyopathy (DCM).

\section{Methods}

We retrospectively evaluated 150 patients who underwent CMR (1.5 T, Siemens) in a time span of 22 months: 50 negative (mean age \pm standard deviation $47 \pm 12.2$ years), 50 with CAD (65 \pm 9.7 years) and 50 with DCM (56 \pm 12.8 years). For each patient we segmented manually the EAT in short-axis cine images at end-diastolic phase with Syngo-Argus software. Volume of EAT was converted into $\mathrm{g}$ ( $\mathrm{g}=0.9196 *$ volume). Intra and inter-reader reproducibility in a sub-group of 30 randomly selected patients (10 negative, 10 with CAD, 10 with DCM) was tested. Mann Whitney $U$ and Bland-Altman test were used.

\section{Results}

Mean EAT in negative, CAD and DCM patients was 18.17 $\pm 10 \mathrm{~mL}, 35.07 \pm 8 \mathrm{~mL}$ and $29.76 \pm 13 \mathrm{~mL}$ respectively. A significant correlation was found comparing negative patients vs CAD ( $\mathrm{p}<0.001)$ and DCM ( $<<0.001)$. No correlation was found comparing CAD vs DCM $(\mathrm{p}=0.890)$. Overall intra and inter-reader reproducibility was up to $83 \%$ and $76 \%$, respectively.

Radiology, IRCCS Policlinico San Donato, Milan, Italy

\section{Conclusions}

A significant difference of EAT amount between patients with CAD or DCM and negative patients was shown, adding more evidence to a correlation between EAT and the presence/absence ischemic or dilated cardiomyopathies.

Published: 27 January 2016

\section{doi:10.1186/1532-429X-18-S1-P89}

Cite this article as: Secchi et al:: Epicardial adipose tissue evaluated with cardiac magnetic resonance in normal subject and in patients with ischemic and dilated cardiomyopathies. Journal of Cardiovascular Magnetic Resonance 2016 18(Suppl 1):P89.

Submit your next manuscript to BioMed Central and take full advantage of:

- Convenient online submission

- Thorough peer review

- No space constraints or color figure charges

- Immediate publication on acceptance

- Inclusion in PubMed, CAS, Scopus and Google Scholar

- Research which is freely available for redistribution 